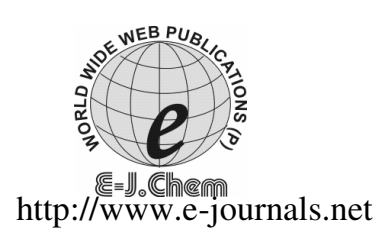

ISSN: 0973-4945; CODEN ECJHAO

E-Journal of Chemistry

2010, 7(4), 1396-1406

\title{
Synthesis, Characterization and Antibacterial Activity of Schiff Bases and their Metal Complexes Derived from 4-Acyl-1-phenyl-3-methyl-2-pyrazolin-5-ones and 2-Amino-4(4'-methylphenyl)thiazole
}

\author{
A.S. THAKAR, K. K .SINGH, K.T. JOSHI ${ }^{\S}$, \\ A.M.PANCHOLI ${ }^{\S}$ and K.S.PANDYA* \\ Zydus Research Centre, Ahmedabad-382 210, India. \\ ${ }^{\S}$ Department of Chemistry, Navjivan Science College, Dahod-389 151, India. \\ *Sir P.T. Science College, Modasa-383 315, India. \\ krishnakant_joshi@yahoo.co.in
}

Received 5 February 2010; Accepted 2 April 2010

\begin{abstract}
Acyl-1-phenyl-3-methyl-2-pyrazolin-5-ones condensed with 2-amino-4(4'-methylphenyl)-thiazole to form Schiff base. These Schiff bases from complexes of type $\mathrm{ML}_{2} 2 \mathrm{H}_{2} \mathrm{O}(\mathrm{M}=\mathrm{Mn}, \mathrm{Fe}, \mathrm{Co}, \mathrm{Ni}$ and $\mathrm{Cu})$. Elemental analysis, magnetic susceptibility, electrical conductance, electronic and Infrared spectral data suggested octahedral structure for the complexes. All the compounds were tested for their antibacterial activity. The result indicates that the growth of the tested organism was inhibited by most of the compounds. These Schiff bases are characterized by elemental analysis, mass spectra, ${ }^{1} \mathrm{H}-$ NMR spectra, ${ }^{13} \mathrm{C}$ NMR spectra and FT IR spectra.
\end{abstract}

Keywords: Pyrazolone, 2-Amino thiazole, Schiff base, Transition metals, Spectroscopy, Antibacterial activity.

\section{Introduction}

Pyrazolone and its derivatives form an important class of organic compounds due to their structural chemistry and biological activities as analgesic, antipyretics, anti-inflammatory and hyper glycemic agents ${ }^{1-4}$. Even the simplest pyrazolone derivatives like antipyrine and amidopyrine are widely used analgesic medicines ${ }^{5}$. 4-Acyl-pyrazolones are efficient extractants of metal ions and they have potential to form different types of coordination compounds due to tautomeric effect of enol and keto form ${ }^{6,7}$. Pyrazolones, especially 4-acyl pyrazolone, display several different coordination modes with respect to classical $\beta$-diketonates ${ }^{8-10}$. In addition 4-acyl-pyrazolones can form a variety of Schiff bases and are reported to be superior reagents in biological, clinical and analytical applications ${ }^{11-14}$. 
In continuation of our work ${ }^{15,16}$ on the metal complexes of Schiff bases, we report here the study of some new, $\mathrm{Mn}(\mathrm{II}), \mathrm{Fe}(\mathrm{II}), \mathrm{Co}(\mathrm{II}), \mathrm{Ni}(\mathrm{II})$ and $\mathrm{Cu}(\mathrm{II})$ complexes of Schiff bases derived from 4-acetyl/benzoyl-1-phenyl-3-methyl-2-pyrazolin-5-ones and 2-amino-4(4'methylphenyl)-thiazole. Preparation, characterization and antibacterial activity of above metal complexes with this Schiff bases AcPMPAMPT and BzPMPAMPT are reported here. Where, AcPMPAMPT is a Schiff base of 2-amino-4(4'-methylphenyl)-thiazole [AMPT] with 4-acetyl-1-phenyl-3-methyl-2-pyrazolin-5-one [AcPMP] and BzPMPAMPT is a Schiff base of 2-amino-4(4'-methylphenyl)-thiazole [AMPT] with 4-benzoyl-1-phenyl-3-methyl-2pyrazolin-5-one [BzPMP].
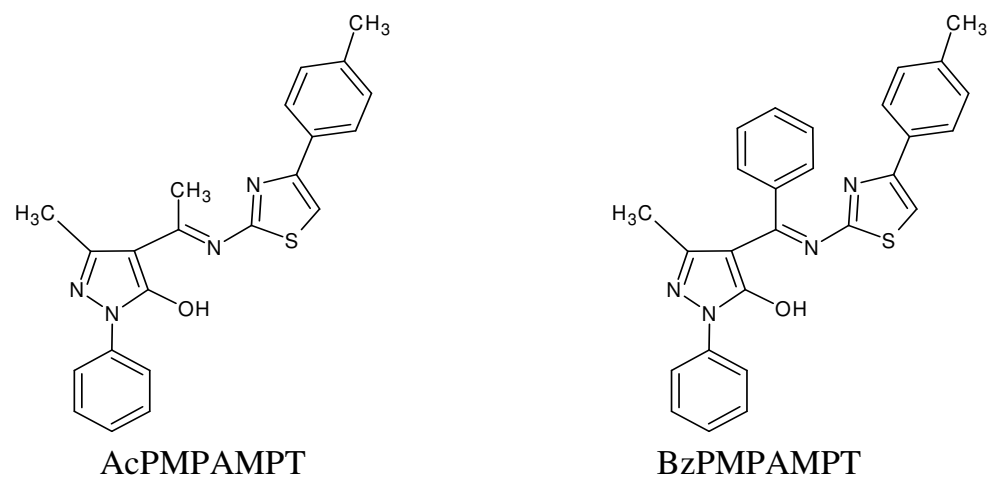

\section{Experimental}

Analytical grade reagents and pure distilled solvent were used throughout the work. The Schiff bases were prepared by condensation of equimolar amount of AMPT ${ }^{17}$ and AcPMP or $\mathrm{BzPMP}^{18}$ in minimum quantity of methanol. The reaction mixture was refluxed in Rota mental for about three hours. On cooling the yellow solid compound obtained was filtered, washed with methanol and dried in air.

Electronic Spectra were recorded in DMF solution on LAMBDA 19, UV/VIS/NIR ("SICART-CVN" at V. V. Nager, Gujarat, India). The Mass spectra of all ligands were recorded on the instrument named LCMS-2010A of make Shimadzu. Carbon, hydrogen and nitrogen were estimated on a Thermo fisher (Thermo electron corporation Limited), Flash Elemental Analyzer-1112. The ${ }^{1} \mathrm{H}$ NMR and ${ }^{13} \mathrm{C}$ NMR spectra in deuterated Chloroform$\mathrm{CDCl}_{3}$ of all ligands were recorded on an AVANCE II 400 of make BRUKER spectrophotometer using TMS $\left[\left(\mathrm{CH}_{3}\right)_{4} \mathrm{Si}\right]$ as internal standard. The infrared spectra of the ligands studied in the present work were recorded on the model FT-IR-8300 of Shimadzu in $\mathrm{KBr}$ (Zydus Research center, Ahmedabad, India).

Spectroscopic analysis of the Schiff bases AcPMPAMPT and BzPMPAMPT are given below.

\section{Experimental data of AcPMPAMPT}

Colour: yellow, melting point: $210^{\circ}-212{ }^{\circ} \mathrm{C}$, yield: $78 \%$; molecular formula $\mathrm{C}_{22} \mathrm{H}_{20} \mathrm{~N}_{4} \mathrm{OS}$; molecular weight: 388.49 ; elemental analysis: calculated: $\mathrm{C}, 68.02 ; \mathrm{H}, 5.19 ; \mathrm{N}, 14.42$; S, 8.25\%; found: C, $67.31 ; \mathrm{H}, 5.17 ; \mathrm{N}, 14.14 ; \mathrm{S}, 8.57 \%$

\section{Mass spectral data}

The positive ion mass spectral analysis of AcPMPAMPT observed at $\mathrm{m} / \mathrm{z} 389.0\left(\mathrm{M}^{+}\right)$, (Figure 1), confirms the theoretical molecular weight i.e. 388.49. 


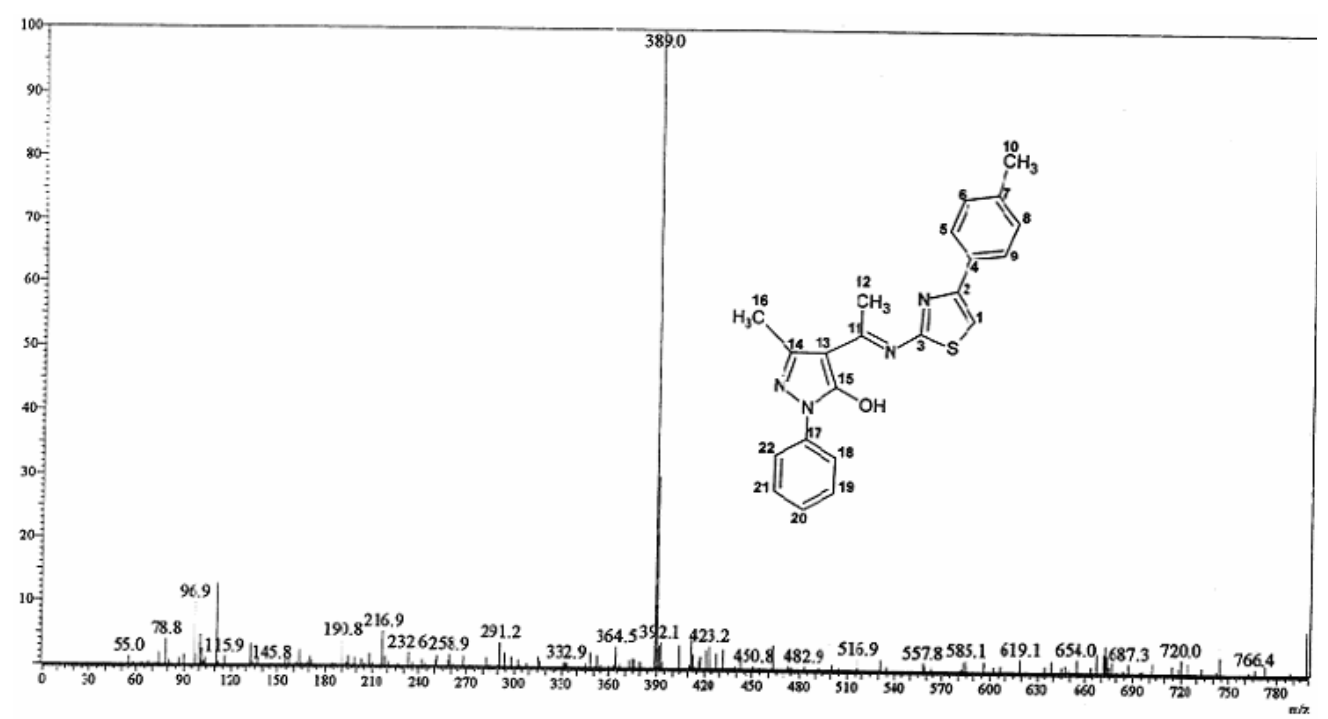

Figure 1. Mass Spectra of AcPMPAMPT

\section{${ }^{1}$ H NMR spectra}

From the recorded ${ }^{1} \mathrm{H}$ NMR spectrum (Figure 2), chemical shifts and the multiplicity of the corresponding protons are; $\left(400 \mathrm{MHz}, \mathrm{CDCl}_{3}\right) \delta=2.38,2.46,2.94\left(\mathrm{~s}, 3 \mathrm{H}, \mathrm{CH}_{3}\right), 7.19-7.99$ (Aromatic proton), 7.15 (thiazole ring), 14.05 (Enolic proton of pyrazolin ring).

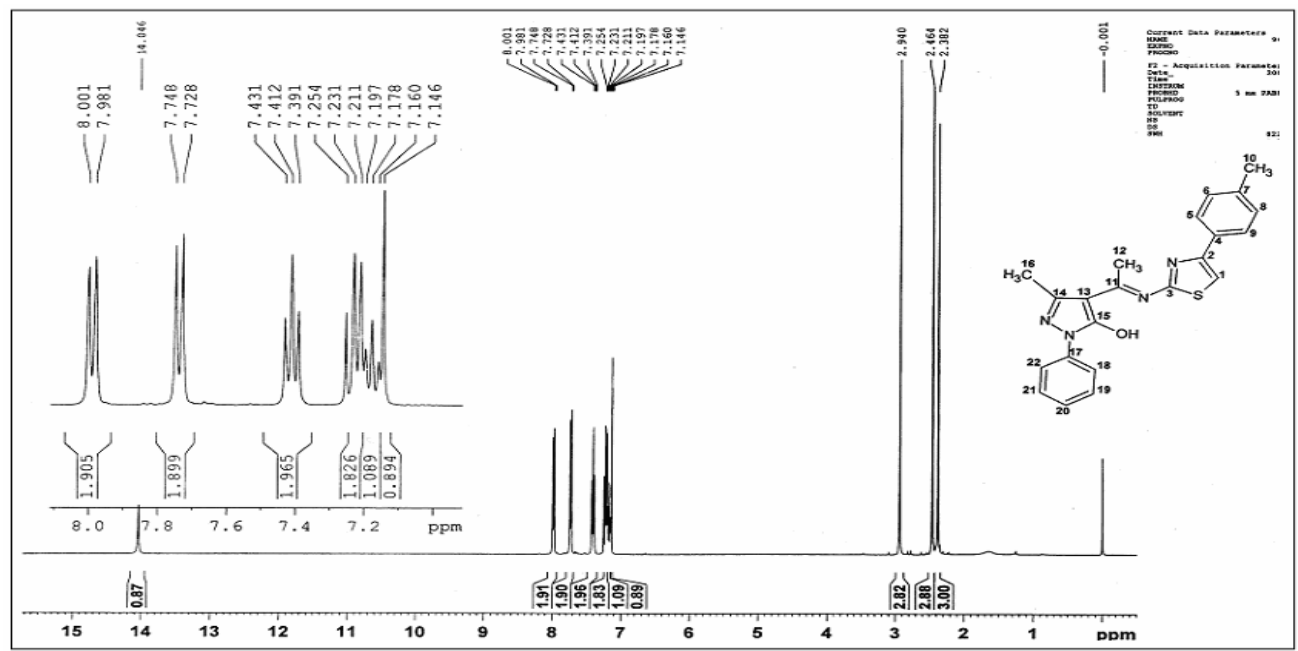

Figure 2. ${ }^{1} \mathrm{H}$ NMR spectra of AcPMPAMPT

\section{${ }^{13}$ C NMR spectra}

From the recorded ${ }^{13} \mathrm{C}$ NMR spectrum (Figure 3), chemical shifts and the multiplicity of the corresponding carbons are; $\left(400 \mathrm{MHz}, \mathrm{CDCl}_{3}\right) \delta=17.93\left(\mathrm{C}_{16}\right), 18.44\left(\mathrm{C}_{10}\right), 21.43\left(\mathrm{C}_{12}\right)$, $103.46\left(\mathrm{C}_{13}\right), 107.76\left({ }_{\mathrm{C} 1}\right), 119.48-128.95$ (Tertiary Aromatic Carbon), $129.60\left(\mathrm{C}_{4}\right), 131.23$ $\left(\mathrm{C}_{7}\right), 138.65\left(\mathrm{C}_{17}\right), 147.90\left(\mathrm{C}_{14}\right), 153.17\left(\mathrm{C}_{2}\right), 159.31\left(\mathrm{C}_{15}\right), 161.13\left(\mathrm{C}_{11}\right), 165.36\left(\mathrm{C}_{3}\right)$. 


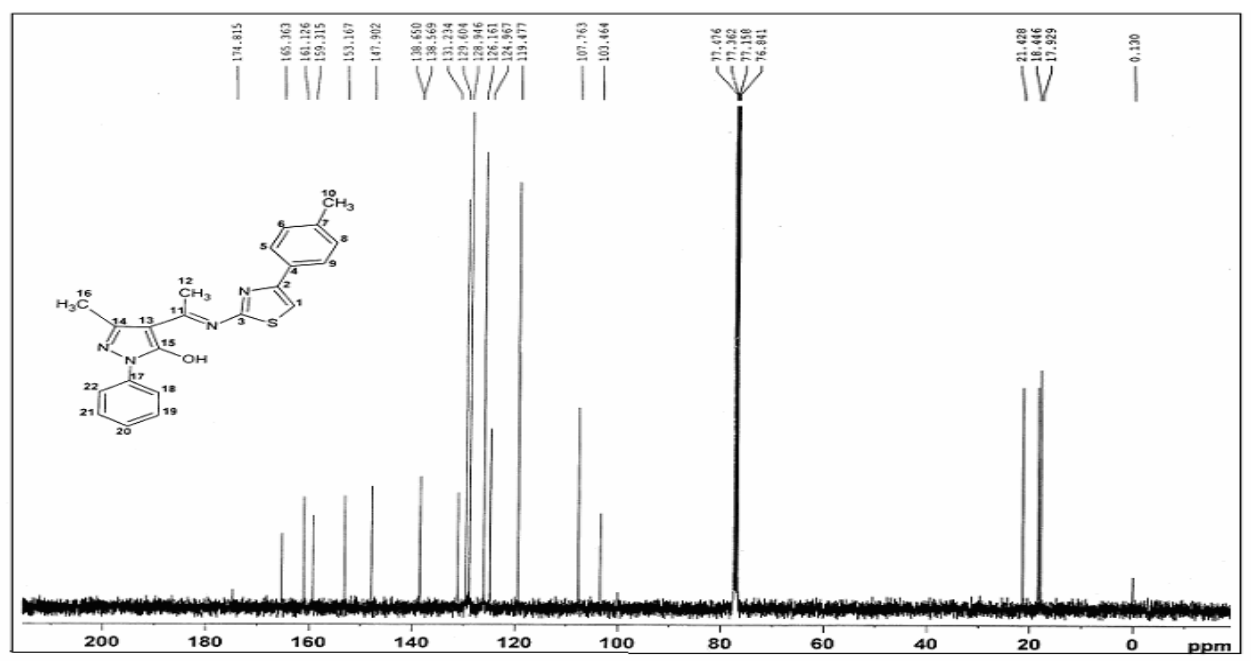

Figure 3. ${ }^{13} \mathrm{C}$ NMR spectra of AcPMPAMPT

\section{FT-Infrared spectra}

From the recorded IR spectrum (Figure 4), the wave numbers of corresponding groups are; $3086.21 \mathrm{~cm}^{-1}\left(v_{\mathrm{CH}}\right.$ Stretching of Aromatic), $2920.32 \mathrm{~cm}^{-1}\left(v_{\mathrm{OH}}\right.$ Stretching of alcohol), $1618.33 \mathrm{~cm}^{-1}$, (v $v_{\mathrm{C}=\mathrm{N}}$ Stretching of amine $), 1593.25 \mathrm{~cm}^{-1}, 1537.67 \mathrm{~cm}^{-1}, 1498.74 \mathrm{~cm}^{-1}$ (Characteristic bands of pyrazolone ring), $1483.31 \mathrm{~cm}^{-1}, 1012.66 \mathrm{~cm}^{-1}$ (Characteristic bands of thiazole ring), $1375 \mathrm{~cm}^{-1}$ ( $v_{\text {C-O }}$ Stretching of alcohol)

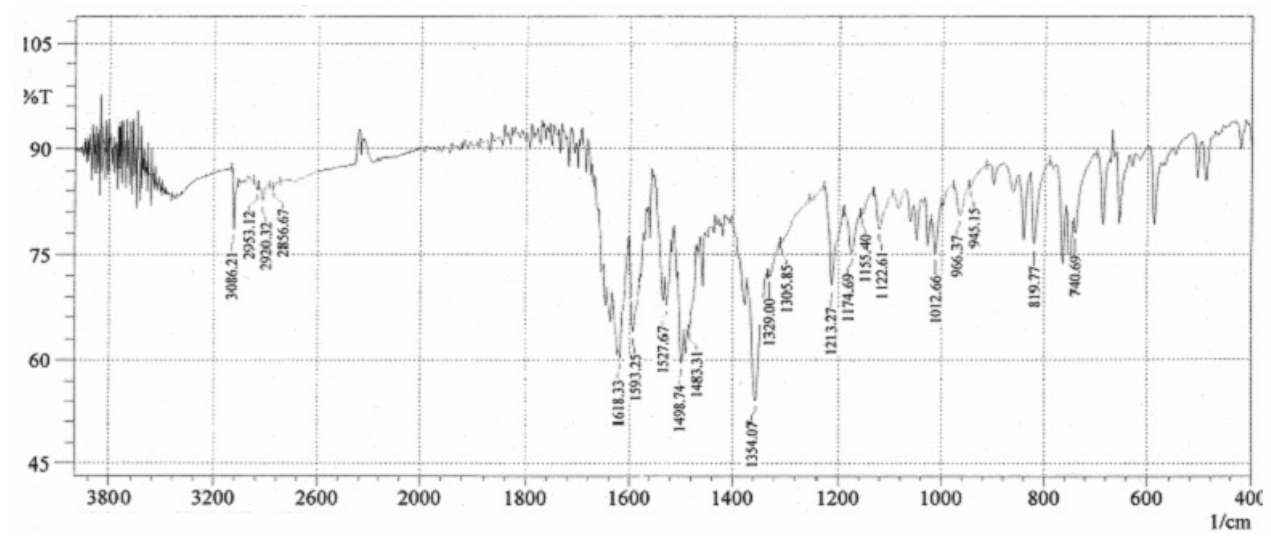

Figure 4. FT IR spectra of AcPMPAMPT

\section{Experimental data of BzPMPAMPT}

Colour: yellow, melting point: $231^{\circ} \mathrm{C}$, yield: $75 \%$, molecular formula: $\mathrm{C}_{27} \mathrm{H}_{22} \mathrm{~N}_{4} \mathrm{OS}$, molecular weight: 450.55 , elemental analysis: calculated $\mathrm{C}, 71.98 ; \mathrm{H}, 4.92 ; \mathrm{N}, 12.44 ; \mathrm{S}$, $7.12 \%$, found C, 70.88; H, 4.84; N, 12.53; S, 7.18\%.

Mass spectral data

The positive ion mass spectral analysis of BzPMPAMPT observe at $m / z 451.0\left(\mathrm{M}^{+}\right)$(Figure 5), confirms the theoretical molecular weight i.e. 450.55 . 


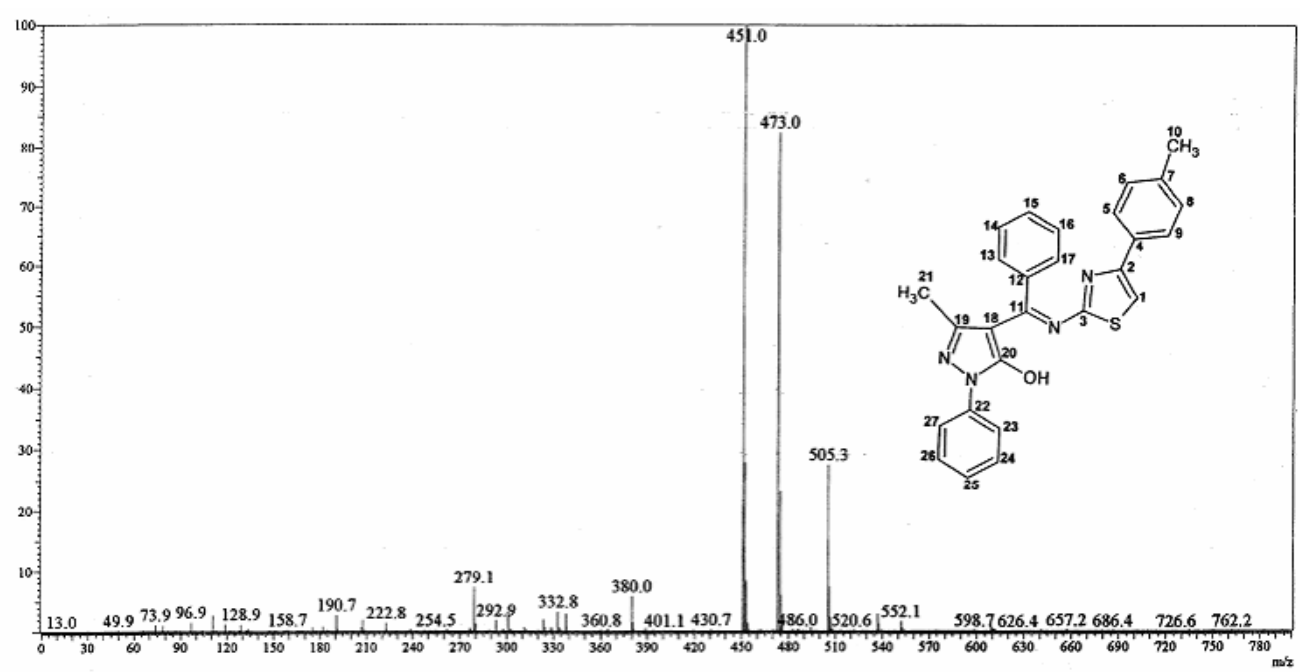

Figure 5. Mass Spectra of BzPMPAMPT

\section{${ }^{1} H$ NMR spectra}

From the recorded ${ }^{1} \mathrm{H}$ NMR spectrum (Figure 6), chemical shifts and the multiplicity of the corresponding protons are; $\left.400 \mathrm{MHz}, \mathrm{CDCl}_{3}\right) \delta=1.50,2.33\left(\mathrm{~s}, \mathrm{CH}_{3}\right), 6.78$ (thiazole ring), 7.16-8.03 (Aromatic Proton), 13.75 (Enolic Proton of Pyrazolin ring).

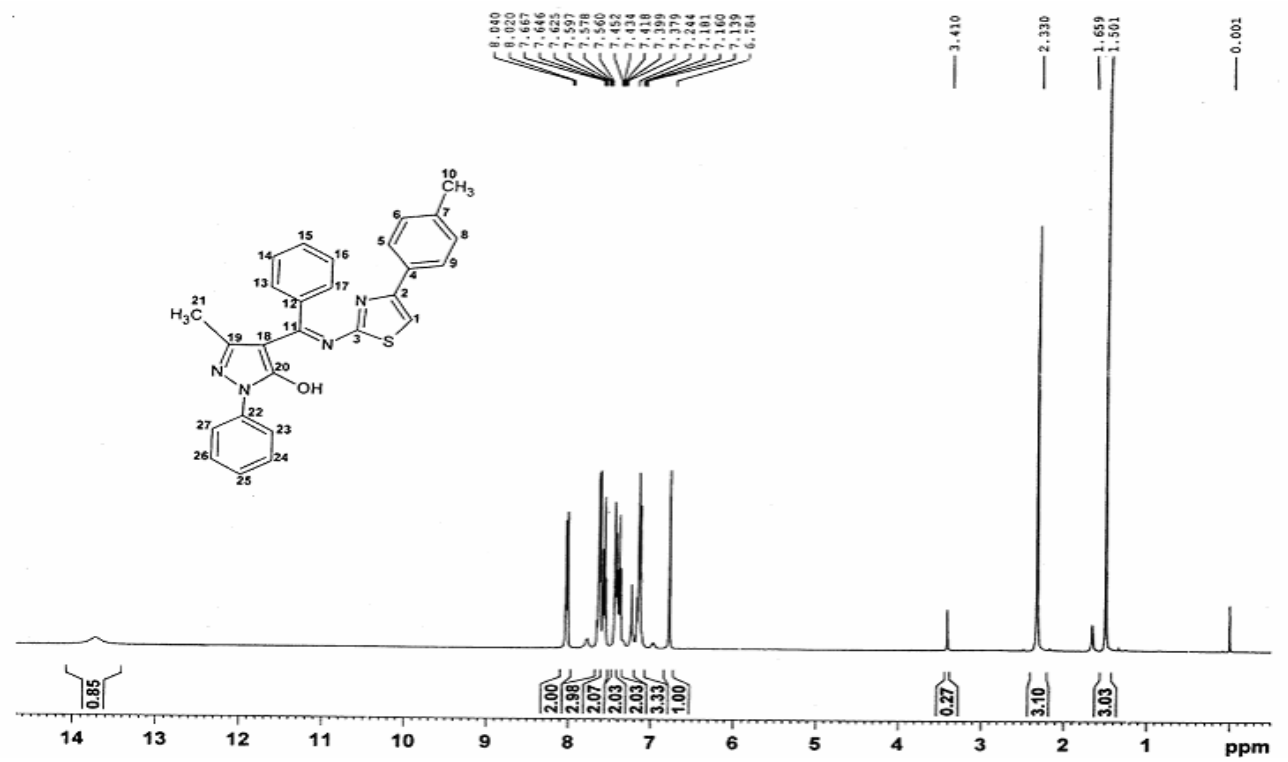

Figure 6. ${ }^{1} \mathrm{H}$ NMR spectra of BzPMPAMPT

\section{${ }^{13}$ C NMR spectra}

From the recorded ${ }^{13} \mathrm{C}$ NMR spectrum (Figure 7), chemical shifts and the multiplicity of the corresponding carbons are; $\left(400 \mathrm{MHz}, \mathrm{CDCl}_{3 .} \delta=15.71\left(\mathrm{C}_{21}\right), 21.41\left(\mathrm{C}_{10}\right), 103.84\left(\mathrm{C}_{18}\right), 108.04\right.$ $\left(\mathrm{C}_{1}\right)$, 119.39-129.73 (tertiary, Aromatic Carbon), 130.95-138.62 (quaternary, Aromatic Carbon) $148.48\left(\mathrm{C}_{19}\right), 151.65\left(\mathrm{C}_{2}\right), 159.01\left(\mathrm{C}_{20}\right), 161.18\left(\mathrm{C}_{11}\right), 165.15\left(\mathrm{C}_{3}\right)$. 


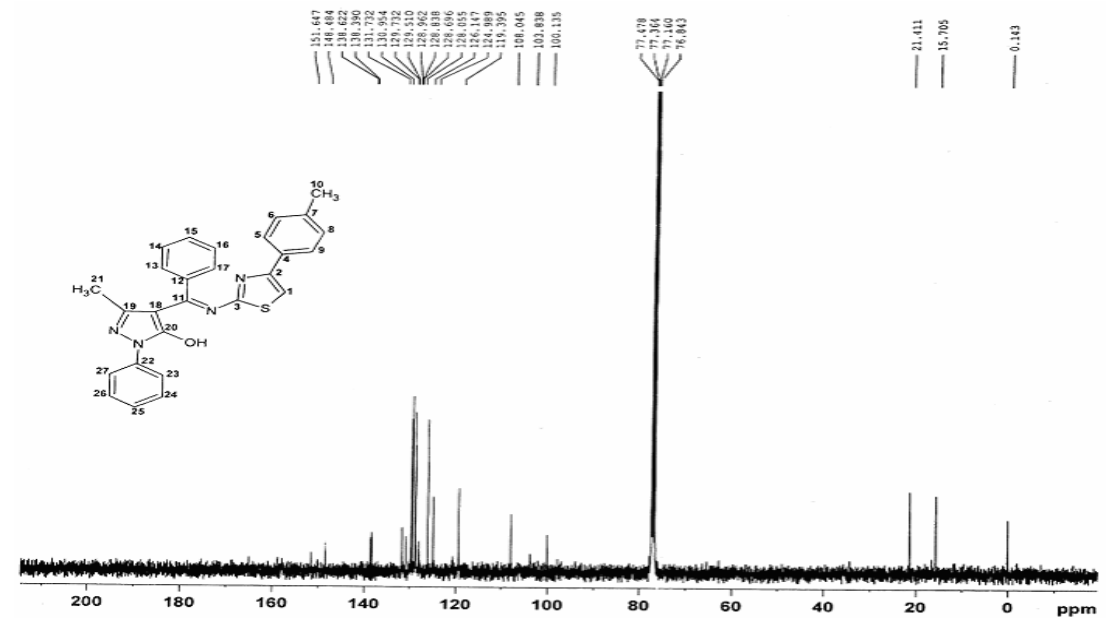

Figure 7. ${ }^{13} \mathrm{C}$ NMR spectra of BzPMPAMPT

\section{FT-Infrared spectra}

From the recorded IR spectrum (Figure 8), the wave numbers of corresponding groups are; $2922.25 \mathrm{~cm}^{-1}$ ( $v_{\mathrm{OH}}$ Stretching of alcohol), $1629.90 \mathrm{~cm}^{-1}$ ( $v_{\mathrm{C}=\mathrm{N}}$ Stretching of amine), $1593.25 \mathrm{~cm}^{-1}$, $1521.89 \mathrm{~cm}^{-1}, 1496.81 \mathrm{~cm}^{-1}$ (Characteristic bands of pyrazolone ring) $1483.31 \mathrm{~cm}^{-1}, 1267.27 \mathrm{~cm}^{-1}$ (Characteristic bands of thiazole ring), $1375 \mathrm{~cm}^{-1}$ (v $\mathrm{C-O}$ Stretching of alcohol).

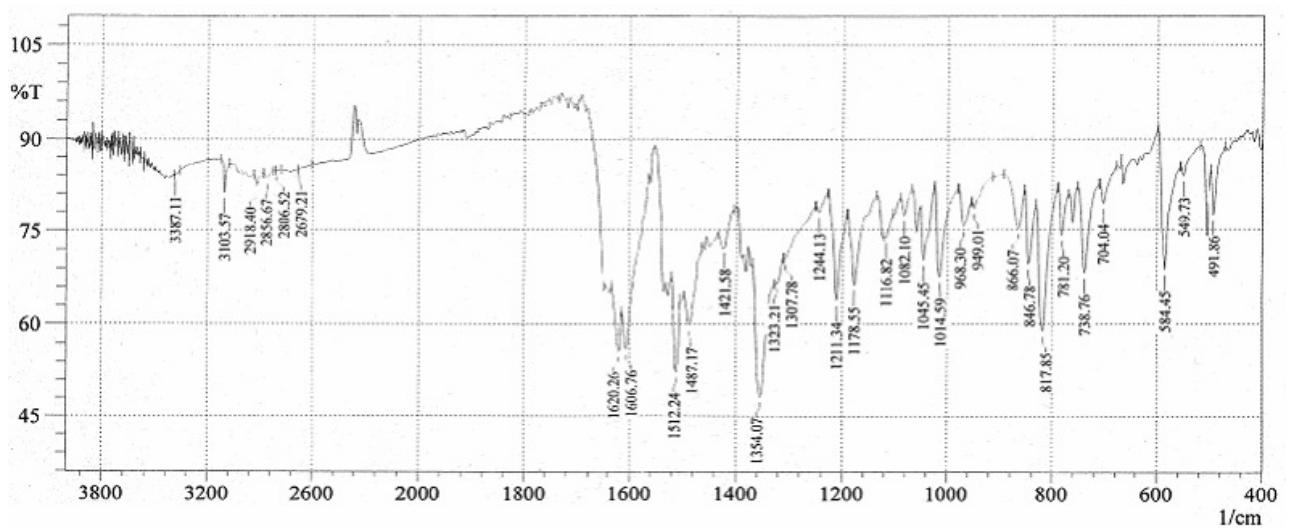

Figure 8. FT IR spectra of BzPMPAMPT

\section{Synthesis and characterization of metal complexes}

For the preparation of complexes, an aqueous solution of metal acetate $(0.05 \mathrm{M})$ and 1:4 dioxane solution of ligand $(0.05 \mathrm{M})$ were mixed in presence of acetate buffer $(\mathrm{pH}=6.5)$ and the mixture was digested on sand bath for 30 minutes, cooled and filtered the precipitate and then washed with water and then methanol to remove excess metal ions and unreacted Schiff bases respectively. The Schiff bases and their metal complexes were tested for antibacterial activity against Escherichia coli, Salmonella typhi and Bacillus.

All the complexes are coloured, non-hygroscopic and stable solids. They are insoluble in water, sparingly soluble in all the common organic solvents but fairly soluble in DMF. Physical properties of the complexes are given in Table 1. The molar conductances of the complexes are in the range of 8.10 to $15.98 \mathrm{ohm}^{-1} \mathrm{~cm}^{2} \mathrm{~mol}^{-1}$ and indicate there non-electrolytic nature. 
Table 1. Analytical and physical data of Schiff base ligands and complexes

\begin{tabular}{|c|c|c|c|c|c|c|c|c|c|c|c|}
\hline \multirow{2}{*}{ Ligand/Complexes } & \multirow{2}{*}{ Colour } & \multirow{2}{*}{ M F } & \multirow{2}{*}{ M W } & \multirow{2}{*}{$\begin{array}{c}\text { Yield } \\
\%\end{array}$} & \multicolumn{5}{|c|}{ Elemental analysis, \% Found (Calculated) } & \multirow{2}{*}{$\mu_{\text {eff }}$ B.M. } & \multirow{2}{*}{$\begin{array}{c}\lambda_{\mathrm{M}} \\
\mathrm{Ohm}^{-1} \mathrm{~cm}^{2} \mathrm{~mol}^{-1}\end{array}$} \\
\hline & & & & & $\mathrm{C}$ & $\mathrm{H}$ & $\mathrm{N}$ & $\mathrm{S}$ & $\mathrm{M}$ & & \\
\hline (AcPMPAMPT) & Yellow & $\mathrm{C}_{22} \mathrm{H}_{20} \mathrm{~N}_{4} \mathrm{OS}$ & 388.49 & 78 & $\begin{array}{c}67.31 \\
(68.02)\end{array}$ & $\begin{array}{c}5.17 \\
(5.19)\end{array}$ & $\begin{array}{c}14.14 \\
(14.42)\end{array}$ & $\begin{array}{c}8.57 \\
(8.25)\end{array}$ & - & - & - \\
\hline $\mathrm{Mn}(\mathrm{AcPMPAMPT})_{2} \cdot 2 \mathrm{H}_{2} \mathrm{O}$ & Creamy & $\mathrm{C}_{44} \mathrm{H}_{42} \mathrm{MnN}_{8} \mathrm{O}_{4} \mathrm{~S}_{2}$ & 865.92 & 56 & $\begin{array}{r}61.09 \\
(61.03)\end{array}$ & $\begin{array}{c}4.86 \\
(4.89)\end{array}$ & $\begin{array}{l}12.84 \\
(12.94)\end{array}$ & $\begin{array}{c}6.30 \\
(6.34)\end{array}$ & $\begin{array}{c}7.48 \\
(7.41)\end{array}$ & 5.59 & 08.26 \\
\hline $\mathrm{Fe}(\mathrm{AcPMPAMPT})_{2} \cdot 2 \mathrm{H}_{2} \mathrm{O}$ & Brown & $\mathrm{C}_{44} \mathrm{H}_{42} \mathrm{FeN}_{8} \mathrm{O}_{4} \mathrm{~S}_{2}$ & 866.83 & 59 & $\begin{array}{c}60.93 \\
(60.97)\end{array}$ & $\begin{array}{c}4.85 \\
(4.88)\end{array}$ & $\begin{array}{c}12.87 \\
(12.93)\end{array}$ & $\begin{array}{c}6.39 \\
(6.44)\end{array}$ & $\begin{array}{l}7.36 \\
(7.40)\end{array}$ & 4.86 & 12.30 \\
\hline $\mathrm{Co}(\mathrm{AcPMPAMPT})_{2} 2 \mathrm{H}_{2} \mathrm{O}$ & $\begin{array}{c}\text { Dark } \\
\text { brown }\end{array}$ & $\mathrm{C}_{44} \mathrm{H}_{42} \mathrm{CoN}_{8} \mathrm{O}_{4} \mathrm{~S}_{2}$ & 869.92 & 66 & $\begin{array}{c}60.72 \\
(60.75)\end{array}$ & $\begin{array}{c}4.80 \\
(4.87)\end{array}$ & $\begin{array}{c}12.89 \\
(12.87)\end{array}$ & $\begin{array}{c}6.71 \\
(6.77)\end{array}$ & $\begin{array}{c}7.41 \\
(7.36)\end{array}$ & 4.47 & 14.31 \\
\hline $\mathrm{Ni}(\mathrm{AcPMPAMPT})_{2} \cdot 2 \mathrm{H}_{2} \mathrm{O}$ & Green & $\mathrm{C}_{44} \mathrm{H}_{42} \mathrm{~N}_{8} \mathrm{NiO}_{4} \mathrm{~S}_{2}$ & 869.68 & 61 & $\begin{array}{c}60.72 \\
(60.77)\end{array}$ & $\begin{array}{c}4.92 \\
(4.87)\end{array}$ & $\begin{array}{l}12.83 \\
(12.88)\end{array}$ & $\begin{array}{c}6.69 \\
(6.75)\end{array}$ & $\begin{array}{c}7.41 \\
(7.37)\end{array}$ & 2.91 & 11.31 \\
\hline $\mathrm{Cu}(\mathrm{AcPMPAMPT})_{2} \cdot 2 \mathrm{H}_{2} \mathrm{O}$ & Brown & $\mathrm{C}_{44} \mathrm{H}_{42} \mathrm{CuN}_{8} \mathrm{O}_{4} \mathrm{~S}_{2}$ & 874.53 & 77 & $\begin{array}{c}60.39 \\
(60.43)\end{array}$ & $\begin{array}{c}4.82 \\
(4.84)\end{array}$ & $\begin{array}{l}12.79 \\
(12.81)\end{array}$ & $\begin{array}{c}7.21 \\
(7.27)\end{array}$ & $\begin{array}{c}7.29 \\
(7.33)\end{array}$ & 1.86 & 12.12 \\
\hline (BzPMPAMPT) & Yellow & $\mathrm{C}_{27} \mathrm{H}_{22} \mathrm{~N}_{4} \mathrm{OS}$ & 450.55 & 75 & $\begin{array}{c}70.88 \\
(71.98)\end{array}$ & $\begin{array}{c}4.84 \\
(4.92)\end{array}$ & $\begin{array}{c}12.53 \\
(12.44)\end{array}$ & $\begin{array}{c}7.18 \\
(7.12)\end{array}$ & - & - & - \\
\hline $\mathrm{Mn}(\mathrm{BzPMPAMPT})_{2} \cdot 2 \mathrm{H}_{2} \mathrm{O}$ & Creamy & $\mathrm{C}_{54} \mathrm{H}_{46} \mathrm{MnN}_{8} \mathrm{O}_{4} \mathrm{~S}_{2}$ & 990.06 & 59 & $\begin{array}{c}65.48 \\
(65.51)\end{array}$ & $\begin{array}{c}4.72 \\
(4.68)\end{array}$ & $\begin{array}{l}11.28 \\
(11.32)\end{array}$ & $\begin{array}{c}5.48 \\
(5.55)\end{array}$ & $\begin{array}{c}6.44 \\
(6.48)\end{array}$ & 5.81 & 15.98 \\
\hline $\mathrm{Fe}(\mathrm{BzPMPAMPT})_{2} . .2 \mathrm{H}_{2} \mathrm{O}$ & Brown & $\mathrm{C}_{54} \mathrm{H}_{46} \mathrm{FeN}_{8} \mathrm{O}_{4} \mathrm{~S}_{2}$ & 990.97 & 57 & $\begin{array}{c}65.49 \\
(65.45)\end{array}$ & $\begin{array}{c}4.66 \\
(4.68)\end{array}$ & $\begin{array}{c}11.28 \\
(11.31)\end{array}$ & $\begin{array}{c}5.69 \\
(5.64)\end{array}$ & $\begin{array}{c}6.49 \\
(6.47)\end{array}$ & 5.19 & 12.09 \\
\hline $\mathrm{Co}(\mathrm{BzPMPAMPT})_{2} . .2 \mathrm{H}_{2} \mathrm{O}$ & $\begin{array}{l}\text { Dark } \\
\text { brown }\end{array}$ & $\mathrm{C}_{54} \mathrm{H}_{46} \mathrm{CoN}_{8} \mathrm{O}_{4} \mathrm{~S}_{2}$ & 994.06 & 60 & $\begin{array}{c}65.24 \\
(65.25)\end{array}$ & $\begin{array}{c}4.60 \\
(4.66)\end{array}$ & $\begin{array}{l}11.25 \\
(11.27)\end{array}$ & $\begin{array}{c}5.89 \\
(5.93)\end{array}$ & $\begin{array}{c}6.40 \\
(6.45)\end{array}$ & 4.42 & 08.10 \\
\hline $\mathrm{Ni}(\mathrm{BzPMPAMPT})_{2} . .2 \mathrm{H}_{2} \mathrm{O}$ & Green & $\mathrm{C}_{54} \mathrm{H}_{46} \mathrm{~N}_{8} \mathrm{NiO}_{4} \mathrm{~S}_{2}$ & 993.81 & 56 & $\begin{array}{c}65.22 \\
(65.26)\end{array}$ & $\begin{array}{c}4.66 \\
(4.67)\end{array}$ & $\begin{array}{l}11.30 \\
(11.28)\end{array}$ & $\begin{array}{c}5.97 \\
(5.91)\end{array}$ & $\begin{array}{c}6.42 \\
(6.45)\end{array}$ & 3.08 & 09.18 \\
\hline $\mathrm{Cu}(\mathrm{BzPMPAMPT})_{2} \cdot 2 \mathrm{H}_{2} \mathrm{O}$ & Brown & $\mathrm{C}_{54} \mathrm{H}_{46} \mathrm{CuN}_{8} \mathrm{O}_{4} \mathrm{~S}_{2}$ & 998.67 & 60 & $\begin{array}{c}64.89 \\
(64.94)\end{array}$ & $\begin{array}{c}4.59 \\
(4.64)\end{array}$ & $\begin{array}{l}11.26 \\
(11.22)\end{array}$ & $\begin{array}{c}6.33 \\
(6.36)\end{array}$ & $\begin{array}{c}6.38 \\
(6.42)\end{array}$ & 1.91 & 10.48 \\
\hline
\end{tabular}


The metal contents in all the complexes were determined gravimetrically as $\mathrm{MoO}_{3}$ by the method reported by Mohanti et al ${ }^{19}$. Carbon, hydrogen and nitrogen were determined micro analytically. Molar conductivities in $10^{-3} \mathrm{M}$ DMF were measured using "Equiptronics EQ-660 digital conductivity meter" and a calibrated conductivity cell at room temperature. Magnetic susceptibilities of the complexes were measured at room temperature $\left(30{ }^{\circ} \mathrm{C}\right)$ using Gouy balance (Sartorius, semi-micro, Sardar Patel University, Vidhyanager, India). Analytical and physical data of Schiff base ligands and complexes are given below.

\section{Infrared spectral analysis of ligands and metal complexes}

The infrared spectra of the ligands show $v_{\mathrm{O}-\mathrm{H}}$ (weakly H-bonded) at $2920.32 \mathrm{~cm}^{-1}$ and $2922.25 \mathrm{~cm}^{-1}$ respectively ${ }^{20}$. The absence of this band in all the metal complexes indicates the removal of proton of hydroxyl group of pyrazolin ring during the chelation. This is further supported by the shift of C-O frequency from $\sim 1375 \mathrm{~cm}^{-1}$ (in ligand) to the higher frequency $1385-1410 \mathrm{~cm}^{-1}$ (in complexes) ${ }^{21}$. The sharp intense band at $1618.33 \mathrm{~cm}^{-1}$ and $1629.90 \mathrm{~cm}^{-1}$ in the ligands can be assigned to $v_{\mathrm{C}=\mathrm{N}}$ (azomethine). A downward shift $\left(\Delta v=15-35 \mathrm{~cm}^{-1}\right)$ in $v_{\mathrm{C}=\mathrm{N}}$ (azomethine) is observed upon coordination indicating that the nitrogen of azomethine group is involved in coordination. All the complexes show broad band in the region $3300 \mathrm{~cm}^{-1}$ to $3550 \mathrm{~cm}^{-1}$ which may be assigned to $v$ о-н of coordinated water ${ }^{22}$. To account for the octahedral stereochemistry of the metal complexes, the coordination of two water molecules is expected.

The bands at $\sim 455 \mathrm{~cm}^{-1}$ in Mn(II) complexes, $\sim 465 \mathrm{~cm}^{-1}$ in Fe(II) complexes, $\sim 520 \mathrm{~cm}^{-1}$ in $\mathrm{Co}$ (II) complexes, $\sim 550 \mathrm{~cm}^{-1}$ in $\mathrm{Ni}$ (II) complexes and $\sim 485 \mathrm{~cm}^{-1}$ in $\mathrm{Cu}$ (II) complexes may be due to metal-nitrogen stretching vibration ${ }^{23,24}$. A less intense band at $\sim 1625 \mathrm{~cm}^{-1}$ in the spectrum of ligand may be assigned to $v_{\mathrm{C}=\mathrm{N}}(\operatorname{ring})^{25}$. All the metal complexes do not show shifting in $v_{\mathrm{C}=\mathrm{N}}$ compared to its respective ligands. This suggests that the nitrogen atom of the ring has not participated in the chelation. However, in water containing chelates, this band is observed as a broad with structure this may be due to coupling of the bending mode of coordinated ${ }^{26}$ water molecules with $v_{\mathrm{C}=\mathrm{N}}$.

\section{Electronic spectra and magnetic studies}

Both the ligands show three absorption bands at $35842.29 \mathrm{~cm}^{-1}, 31545.74 \mathrm{~cm}^{-1}, 26525.19 \mathrm{~cm}^{-1}$ and $35714.28 \mathrm{~cm}^{-1,} 30303.03 \mathrm{~cm}^{-1}, 26109.66 \mathrm{~cm}^{-1}$ respectively. No absorption was observed in the visible region for any of the ligands. In the absence of quantum mechanical calculation, it is not possible to assign the absorption bands to definite electronic transitions with complete certainty. However, it appears reasonable to assign the bands to $\pi \rightarrow \pi^{*}$ transitions ${ }^{27}$. The electronic spectra of $\mathrm{Mn}(\mathrm{II})$ complexes exhibit three very low intense bands, one at $16949.15 \mathrm{~cm}^{-1}, 17324.2 \mathrm{~cm}^{-1}$ respectively which may rise due to ${ }^{6} \mathrm{~A}_{\mathrm{gg}} \rightarrow{ }^{4} \mathrm{~T}_{1 \mathrm{~g}}$ (G) transition, another at $20090.32 \mathrm{~cm}^{-1}$ and $20230.02 \mathrm{~cm}^{-1}$ assigned to ${ }^{6} \mathrm{~A}_{1 \mathrm{~g}} \rightarrow{ }^{4} \mathrm{~A}_{1 \mathrm{~g}}(\mathrm{G})$ transition and the third at $25850 \mathrm{~cm}^{-1}, 26490 \mathrm{~cm}^{-1}$ assigned to ${ }^{6} \mathrm{~A}_{1 \mathrm{~g}} \rightarrow{ }^{4} \mathrm{~A}_{1 \mathrm{~g}},{ }^{4} \mathrm{E}_{\mathrm{g}},(\mathrm{G})$ transition for $\mathrm{Mn}(\mathrm{II})$ ion in octahedral environment. The $\mu_{\mathrm{eff}}$ (Table 1) value of the complexes suggests the spin $3 \mathrm{~d}^{5}$ configuration ${ }^{28}$. The electronic spectra of all Fe(II) complexes shows a broad band at $16393.44 \mathrm{~cm}^{-1}, 16590 \mathrm{~cm}^{-1}$ respectively which may be assigned to the ${ }^{5} \mathrm{~T}_{2 \mathrm{~g}} \rightarrow{ }^{5} \mathrm{E}_{\mathrm{g}}$ transition. The magnetic moment value 4.92 and $5.14 \mathrm{BM}$ respectively which indicates that the complexes are spin-free and it has octahedral geometry. The electronic spectra of Co(II) complexes exhibited absorption bands in the region $8050 \mathrm{~cm}^{-1}$ to $10550 \mathrm{~cm}^{-1}$ and $18100 \mathrm{~cm}^{-1}$ to $20100 \mathrm{~cm}^{-1}$ corresponding to $v_{1}$ and $v_{3}$ transitions ${ }^{4} \mathrm{~T}_{1 \mathrm{~g}}(\mathrm{~F}) \rightarrow{ }^{4} \mathrm{~T}_{2 \mathrm{~g}}(\mathrm{~F})\left(v_{1}\right) ;{ }^{4} \mathrm{~T}_{1 \mathrm{~g}}(\mathrm{~F}) \rightarrow{ }^{4} \mathrm{~T}_{1 \mathrm{~g}}(\mathrm{P})$ $\left(v_{3}\right)$. In the present investigation, $\mathrm{Co}(\mathrm{II})$ complexes show the absorption bands at $9540 \mathrm{~cm}^{-1}$, $11363.63 \mathrm{~cm}^{-1}$ and $17650 \mathrm{~cm}^{-1}, 18210 \mathrm{~cm}^{-1}$ corresponding to $v_{1}$ and $v_{3}$ transitions respectively. 
These bands are the characteristics of high spin octahedral Co(II) complexes. However, $v_{2}$ band is not observed because of its proximity to strong $v_{3}$ transition. The magnetic measurement of $\mathrm{Co}(\mathrm{II})$ complexes display magnetic moment value of 4.76 B.M. which is in the octahedral range 4.45 to 4.53 B.M. The greenish Ni(II) complexes exhibited three bands at $10400 \mathrm{~cm}^{-1}, 15740 \mathrm{~cm}^{-1}$ and $26500 \mathrm{~cm}^{-1}$ as well as three bands at $10550 \mathrm{~cm}^{-1} 15830 \mathrm{~cm}^{-1}$ and $26450 \mathrm{~cm}^{-1}$ which are attributed to the ${ }^{3} \mathrm{~A}_{2 \mathrm{~g}} \rightarrow{ }^{3} \mathrm{~T}_{2 \mathrm{~g}}(\mathrm{~F})\left(\mathrm{v}_{1}\right) ;{ }^{3} \mathrm{~A}_{2 \mathrm{~g}} \rightarrow{ }^{3} \mathrm{~T}_{1 \mathrm{~g}}(\mathrm{~F})\left(\mathrm{v}_{2}\right)$ and ${ }^{3} \mathrm{~A}_{2 \mathrm{~g}} \rightarrow{ }^{3} \mathrm{~T}_{1 \mathrm{~g}}(\mathrm{p})$ $\left(\mathrm{v}_{3}\right)$ transitions respectively indicating octahedral geometry around $\mathrm{Ni}$ (II) ion. $\mathrm{Ni}$ (II) complexes showed the magnetic moment value of 3.28 which is in the range of 2.98 to 3.02 B.M suggesting consistency with their octahedral environment ${ }^{34}$. For the $\mathrm{Cu}(\mathrm{II})$ complexes with $\mathrm{D}_{4} \mathrm{~h}$ symmetry, three spin allowed transitions ${ }^{2} \mathrm{~B}_{1 \mathrm{~g}} \rightarrow{ }^{2} \mathrm{~A}_{1 \mathrm{~g}}\left(v_{1}\right),{ }^{2} \mathrm{~B}_{1 \mathrm{~g}} \rightarrow{ }^{2} \mathrm{~B}_{2 \mathrm{~g}}\left(\mathrm{v}_{2}\right)$ and ${ }^{2} \mathrm{~B}_{1 \mathrm{~g}} \rightarrow{ }^{2} \mathrm{E}_{\mathrm{g}}\left(v_{3}\right)$ are possible but the electronic spectra of $\mathrm{Cu}$ (II) complexes display two bands at $14388.48 \mathrm{~cm}^{-1}$, $21180 \mathrm{~cm}^{-1}$ and $14730 \mathrm{~cm}^{-1}, 21460 \mathrm{~cm}^{-1}$ respectively. There should be third transition but we could not observe the same which may be due to very close energy values of different states. Absence of any spectral band below $10000 \mathrm{~cm}^{-1}$ rule out the possibility for tetrahedral structure of the present complexes are also suggestive for distorted octahedral geometry of the complexes $^{29}$. The low molar conductance values in DMF solution for all metal complexes (Table 1) are indicating that the complexes are non-electrolytes.

\section{Antibacterial activity}

The compounds were tested in vitro for the Antibacterial activity against Escherichia coli gram negative bacteria (responsible for diarrhea) (I), Bacillus subtillis-gram positive rods (general contaminant)(II) and Staphylococcus aureus gram positive spore forming rods (causative agent for wound infection) (III) using Agar cup assay method.

The degree of effectiveness was measured by determining the diameters of the zone of inhibition caused by the compounds. Effectiveness was classified into three zones on the bases of their diameter of zone of inhibition.

$$
\begin{array}{ll}
+++ & : \text { Most effective } \\
++ & : \text { Moderate effective } \\
+ & : \text { Slightly effective } \\
- & \text { : Non effective }
\end{array}
$$

Most of the compounds were moderate active against both gram (-) negative and gram (+) positive bacteria. The results are presented in Table 2 .

Table 2. Antibacterial activity of the compounds

\begin{tabular}{clccc}
\hline S No & \multicolumn{1}{c}{ Compound } & E. Coli & B. Subtilis & S. Aureus \\
\hline 1 & (AcPMPAMPT) & + & + & + \\
2 & Mn(AcPMPAMPT $)_{2} .2 \mathrm{H}_{2} \mathrm{O}$ & ++ & + & ++ \\
3 & $\mathrm{Fe}(\text { AcPMPAMPT })_{2} .2 \mathrm{H}_{2} \mathrm{O}$ & + & ++ & + \\
4 & $\mathrm{Co}(\text { AcPMPAMPT })_{2} 2 \mathrm{H}_{2} \mathrm{O}$ & ++ & + & ++ \\
5 & $\mathrm{Ni}(\text { AcPMPAMPT })_{2} .2 \mathrm{H}_{2} \mathrm{O}$ & ++ & ++ & ++ \\
6 & $\mathrm{Cu}(\text { AcPMPAMPT })_{2} .2 \mathrm{H}_{2} \mathrm{O}$ & ++ & + & ++ \\
7 & $($ BzPMPAMPT $)$ & + & + & + \\
8 & $\mathrm{Mn}(\text { BzPMPAMPT })_{2} .2 \mathrm{H}_{2} \mathrm{O}$ & ++ & + & + \\
9 & $\mathrm{Fe}(\text { BzPMPAMPT })_{2} . .2 \mathrm{H}_{2} \mathrm{O}$ & + & + & ++ \\
10 & $\mathrm{Co}(\text { BzPMPAMPT })_{2} .2 \mathrm{H}_{2} \mathrm{O}$ & + & ++ & ++ \\
11 & $\mathrm{Ni}(\text { BzPMPAMPT })_{2} . .2 \mathrm{H}_{2} \mathrm{O}$ & ++ & + & ++ \\
12 & $\mathrm{Cu}(\text { BzPMPAMPT })_{2} .2 \mathrm{H}_{2} \mathrm{O}$ & + & ++ & + \\
\hline
\end{tabular}




\section{Conclusion}

On the basis of these results obtained for elemental analysis, infrared spectra and magnetic susceptibility measurements the following structures (Scheme $1 \& 2$ ) are proposed for the complex compounds.

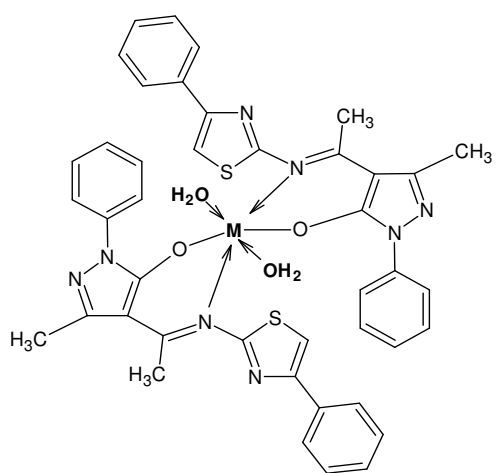

Scheme 1. Where $\mathrm{M}=\mathrm{Mn}(\mathrm{II}), \mathrm{Fe}(\mathrm{II})$, $\mathrm{Co}(\mathrm{II}), \mathrm{Ni}(\mathrm{II})$ and $\mathrm{Cu}(\mathrm{II})$

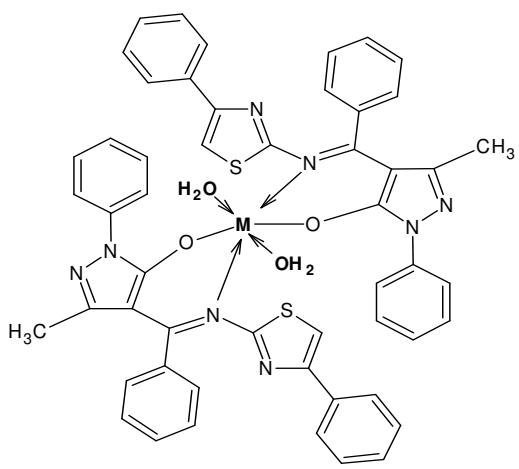

Scheme 2. Where $\mathrm{M}=\mathrm{Mn}(\mathrm{II}), \mathrm{Fe}(\mathrm{II})$, $\mathrm{Co}(\mathrm{II}), \mathrm{Ni}(\mathrm{II})$ and $\mathrm{Cu}(\mathrm{II})$

The synthesized metal complexes in comparison to the uncomplexed Schiff base ligand were screened for their antibacterial activity against pathogenic bacterial species (E. coli, $B$. Subtillis, S. Aurous). The activity of the Schiff base complexes became more pronounced when coordinated with metal ions.

\section{Acknowledgment}

The authors wish to express their gratitude to Dahod Anaj Mahajan Sarvjanik Education Society for laboratory facilities, Principal N.V Patel Science College, V.V Nagar, Anand, Zydus Cadila for spectral analysis and Chintan Shah for antibacterial activity of the complexes.

\section{References}

1. Abbiati G, Arcadi A, Attanasi O A, De Crescentini L and Rossi E, Tetrahedron, 2001, 57, 2031-2038.

2. Ceulemans E, Voets M, Emmers S, Uytterhoeven K, Meervelt L V and Dehaen W, Tetrahedron, 2002, 58, 531-544.

3. Marchatti F, Pettinari C, Cingolani A, Pettinari R, Rossi M and Caruso F, $J$ Organomet Chem., 2002, 645, 134-145.

4. Hassib H B and Abdel-Latif S A, Spectrochim Acta Part A., 2003, 59(11), 2425-2434.

5. Mileva M, Bakalova R, Tancheva L and Galabov A, Arch Toxicol., 2002, 76, 96-103.

6. Wiley R. H and Wiley P, Hetrocyclic compounds: Pyrazolons Pyrazolodines and derivatives, Interscience, New York, 1964.

7. Gooman L S and Gilmam A, The Pharmacological Bases of Therapeutics, Fourth Ed., Macmilan, London, 1970.

8. Uzolukwu B A, Adiukwu P U, Al-juaid S S, Hitchcock P B and Smith J D, Inorg Chim Acta., 1996, 250, 173.

9. Adhikari N, Chaudhuri S, Butcher R J and Saha N, Polyhedron, 1999, 18, 1323-1328.

10. Raman N, Kulandaisamy A, Shummugasundaram A and Jeyasubramanian K, Transit Met Chem., 2001, 26, 131-135. 
11. Iskander M F, El-Sayed L, Hefny A F M and Zayan S E, J Inorg Nucl Chem., 1976, 38, 2209.

12. Havanur G H and Mahale V B, Ind J Chem., 1987, 26A, 1063.

13. Adams H, Fenton D E, Minardi G, Mura E and Angelo M, Inorg Chem Commun., 2000, 3, 24.

14. Yang Z. Y, Yang R D, Li F S and Yu K B, Polyhedron, 2000, 19, 2599.

15. Joshi K T, Dabhi H R, Pancholi A M and Rana A K, Oriental J Chem., 1996, 12(3), 287-290.

16. Joshi K T, Pancholi A M, Rai R K and Franco J, Oriental J Chem., 1997, 13(3), 333-335.

17. Thaker K A and Manjarmakar N R, J Indian Chem Soc., 1971, 48, 621.

18. Jensen B S, Acta Chem Scand., 1959, 13, 1668-1670.

19. Mohanti R, Chakravertty N V and Dass K C, Indian J Chem., 1991, 30, 457.

20. Bellamy L. J, The infrared Spectra of Complex Molecules, $3^{\text {rd }}$ Ed., Chapman and Hall, London, 1975, 1, 108.

21. Patel I A. and Thaker B T, Indian J Chem., 1999, 38A, 431.

22. Rana. A K and Shah J R, Indian J Chem., 1981, 20A, 615.

23. Nakamoto K, Infrared spectra of Inorganic and coordination Compounds, John Willey, New York, 1963.

24. Adans D M, Metal-Ligand and related Vibration”, Edward Arnold, London, 1967, 310.

25. Ocafor E C, J Inorg Nucl Chem., 1980, 42, 1155.

26. Rahman S M F, Ahmad J and Haq M. M, J Inorg Nucl Chem., 1973, 35, 1011 and the reference therein.

27. Uzoukwn B A, Goie K and Duddeck H, Indian J Chem., 1998, 37B, 1180.

28. Dutta R L. and Shyamal A, Element of Magneto Chemistry, Affiliated East-West press, New Delhi, 1982, 38.

29. Figgis B N, Introduction to ligand fields Interscience, New York., 1966, 218. 


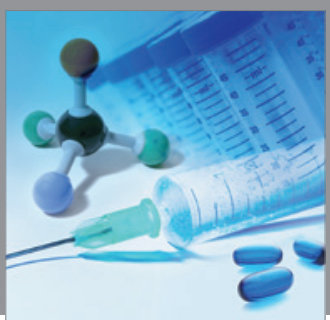

International Journal of

Medicinal Chemistry

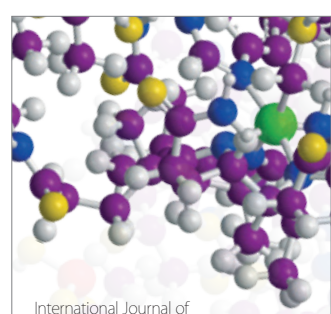

Carbohydrate Chemistry

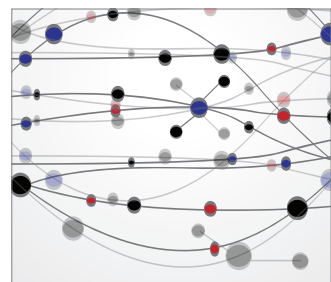

The Scientific World Journal
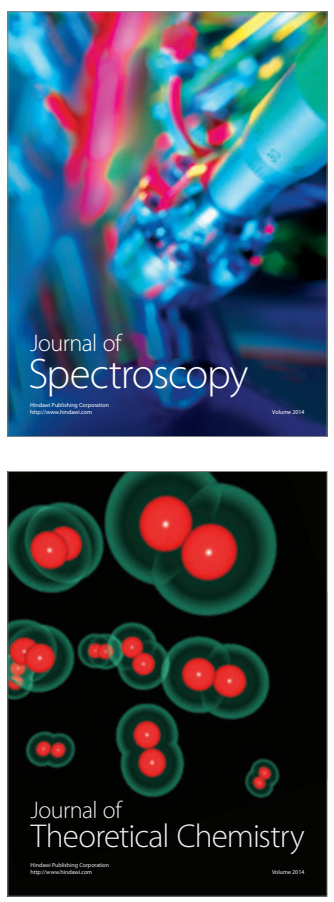
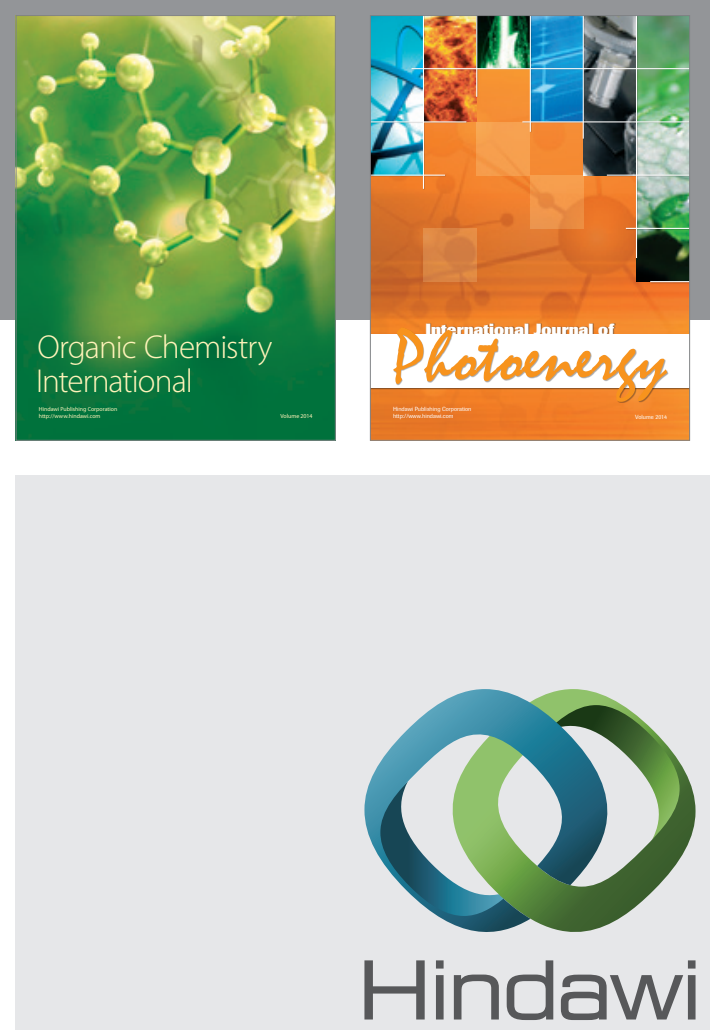

Submit your manuscripts at

http://www.hindawi.com
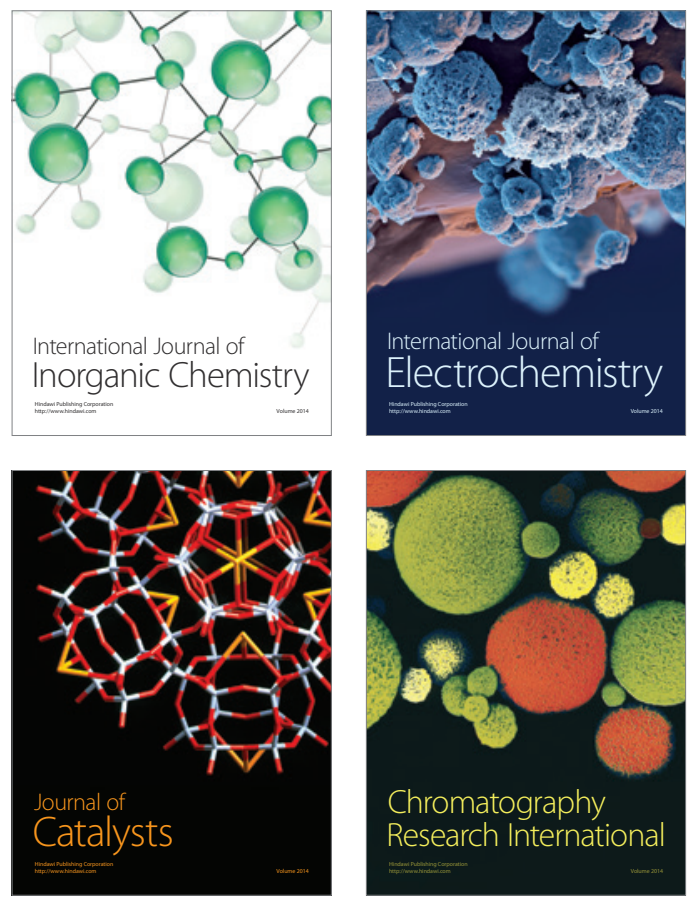
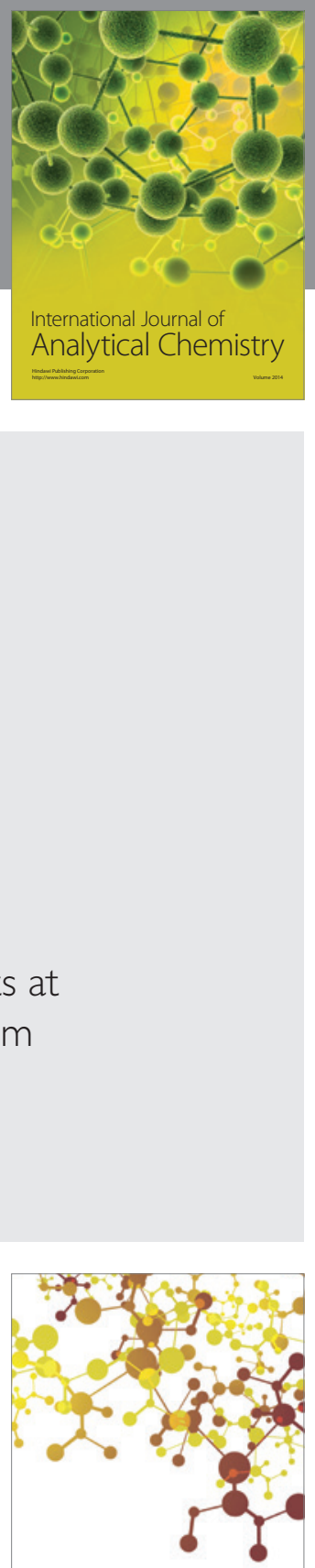

Journal of

Applied Chemistry
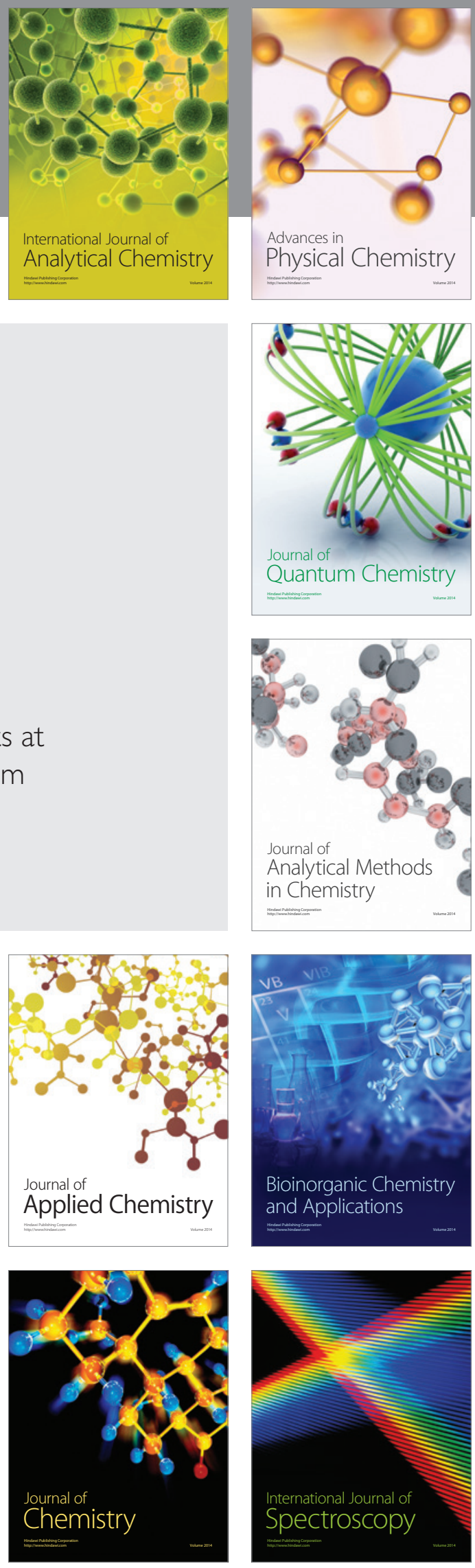